\title{
RAPD based molecular diversity analysis of different varieties of pomegranate (Punica granatum L.)
}

\author{
AMOL S. SHINDE*, SAGAR R.MAHAJAN AND SAGAR H. KAKDE \\ Lokmangal Agricultural Biotechnology College, Wadala, SOLAPUR (M.S.) INDIA \\ (Email: amolshinde0110@gmail.com)
}

\begin{abstract}
Genetic diversity of eight pomegranate varieties was carried out using five RAPD primers. The DNA was extracted from young leaves using CTAB method. The PCR for RAPD was performed with two primers from OPA series, and four primers from OPB series. The RAPD analysis with five arbitrary oligonucleotide primers amplified a total of 28 DNA bands out of which 25 were found to be polymorphic. The average polymorphism recorded by the RAPD loci was 89.28 per cent. The number of DNA fragment varied from four to seven. The mean number of polymorphic bands per primer among eight pomegranate varieties was 5.6 and per cent polymorphism ranged from 75 to 100 . The size of PCR amplified DNA fragment ranged from 88.49 to $1430.11 \mathrm{bp}$ and PIC value varied from 0.70 to 0.83 . The dendrogram constructed using pooled RAPD loci data clearly showed two varieties (Ganesh and Mrudula) were highly similar and different from other genotypes. The genetic similarities ranged from 0.32 to 0.72 and mean similarity co-efficient was 0.61 .
\end{abstract}

Key Words : RAPD, Punica granatum L., PCR, Primer, Molecular marker

View Point Article : Shinde, Amol S., Mahajan, Sagar R. and Kakde, Sagar H. (2015). RAPD based molecular diversity analysis of different varieties of pomegranate (Punica granatum L.). Internat. J. agric. Sci., 11 (1): 141-145.

Article History : Received : 08.10.2014; Revised : 24.11.2014; Accepted : 10.12.2014

\footnotetext{
* Author for correspondence
} 